\title{
RECENT DEVELOPMENTS IN THE WORLD'S LEADING GENERIC MARKETS
}

\author{
Mihajlo B. Jakovljevic \\ Department of Pharmacology and Toxicology, Faculty of Medical Sciences, University of Kragujevac, Kragujevac, Serbia
}

\section{АКТУЕЛНА ДИНАМИКА РАЗВОЈА НА ВОДЕЪИМ ТРЖИШТИМА ГЕНЕРИЧКИХ ЛЕКОВА У СВЕТУ}

\author{
Михајло Б. Јаковљевић \\ Катедра за фармакологију и токсикологију, Факултет медицинских наука, Универзитет у Крагујевиу, Крагујеваи
}

\section{ABSTRACT}

Possible net savings achieved via generic substitution of brand name drugs within the EU healthcare expenditure amount to $€ 30$ billion. In the course of the past 5 years, some of the leading therapy classes, such as oncologics, antihypertensive, antidiabetics, lipid regulators, antipsychotics, platelet aggregation inhibitors, antiulcerants and a few others, experienced fierce generic competition, when blockbuster patents expired. This review aims to describe contemporary circumstances within the leading global generic markets.

Key words: drugs, generic; marketing; economics, medical.

According to the recent European Generic medicines Association estimates, savings within the EU healthcare expenditure achieved by generic substitution amount to $€$ 30 billion (1). In the course of the past 5 years, some of the leading therapy classes, such as oncologics, antihypertensive, antidiabetics, lipid regulators, antipsychotics, platelet aggregation inhibitors, antiulcerants and few others, experienced fierce generic competition, when blockbuster patents expired (1).

In several European countries, such as France, Italy and Switzerland, we can observe the landscape of priceregulated markets. Market uptake of generics remained weak even after a series of policy measures aimed to improve their prescribing and dispensing (2). Significant delay in generic marketing approvals and particularly low hospital substitution rates can be observed in Switzerland. Swiss policy makers have recently voted to implement an array of interventions such as $20 \%$ patient co-payment for brand drugs, aimed at improving generic substitution at least to the average OECD levels. Targeted physician education and provision of abundant secure supply of generic medicines were recognized as major policy goals in future (3).

So called "brand-generics" are relatively recent phenomena, created by the brand manufacturer. These expensive medicines were released by major companies in order to slow down income erosion caused by many governments' efforts to reduce pharmaceutical expenditure. Majority of such generics are present in

\section{САЖЕТАК}

Нето уштеде на трошковима набавке лекова у Европској унији које је могуће извести систематском супституиијом оригиналних лекова генерицима достижу и до 30 милијарди евра према пројекцијама Европске комисије. Током наредних пет година неки од водећих терапијских разреда, попут ичитостатика, антихипертензива, оралних хипогликемика, антилипемика, неуролептика, антиагрегационих лекова, лекова за лечење улкусне болести желуиа и многи други суочили су се са жестоком генеричком конкуренцијом, по истеку патената водећих брендова. Прегледни чланак настоји да опише садашње трендове на кључним светским фармацеутским тржиштима.

Кључне речи: лекови, генерички; маркетинг; економија, здравствена.

Germany (2) although this country is regarded more successful in terms of generic substitution than previously mentioned neighbours. It should be emphasized that these legislatures, thanks to the respective pricing policies, tend to allocate the majority of income from the sales of medicines to the wholesalers and distribution chains.

At the same time, US, Canada, UK and the Netherlands exhibit far more liberal policies with shorter post-patent exclusivity periods and financial incentives for first released generic upon patent expiry. These are therefore long-term leading markets in terms of both volume and value of generic sales nationwide. These economies reward manufacturers properly and most of profit is assigned to the industry. A number of published pharmacoeconomic reports and trials point out to the same universal truth: pharmaceutical overregulation and strict pricing policy drives out competition in high income economies (4).

USA is traditionally remarkable for its 180 days exclusivity period for the first approved generic following patent expiry. Within the so-called "Bolar provision" it is allowed to the generic producer to submit abbreviated request for marketing approval to the FDA containing evidence on bioequivalence with the reference brand product, even before patent expiry (5). This early competition creates sudden and strong profit erosion for 
originator compound and creates downward pressure on generic drug prices (6). Different strategies have been developed by the brand industry to combat these policy challenges. Besides stronger investment in advertising campaigns, many of them targeted to harm competitor's quality and reliability reputation, patenting novel delivery systems for the same active ingredient, merging/acquisitions of generic firms, ultimately up to the direct arrangements with generic manufacturers assuming payments in order them to delay planned market entry. The last one proved to be particularly harmful for the community and the payers of health care (7) keeping drug prices high even after patent expiry. Quite helpful for generic substitution promotion was indeed the highly fragmented financing of US health care. In order to enlarge the profit margin, insurance societies began listing generic medicines within insurance plans of medical services covered by a certain premium. Food and Drug Agency played a historical role in regulating bioequivalence requirements and defining " $\mathrm{A}$ " drug list allowing for free substitution established with the so called "Orange Book". Deeper insight revealed that FDA essentially lacks reach to the ordinary prescriber (physician) and dispenser (pharmacist) because at least half of them do not consult this source in an everyday work (8).

Regardless of some unwanted developments, the US with its substantial support to the free market selfregulation and privileges for generic manufacturers introduces by Waxman-Hetch Act of 1984, remains the most successful in terms of generic market share so far (9). Japan, as the world second largest pharmaceutical market, is famous for its peculiar consumer demand and clear domination of brand name originals for decades. Strong and complex regulatory incentives provided by Governmental policy have provided substantial increase in generic prescribing and dispensing in Japan over the course of the past two decades (10).

New Zealand could serve as an excellent example of the introduction of competitive tenders in order to stimulate decrease of prices and acquisition of the most affordable generics under the precondition of strictly defined bioequivalence and quality standards (11). Australia, on the other hand, has a history of lower pricing freedom and therefore a smaller generic market share (12). Reference pricing was introduced in Australia through its Pharmaceutical Benefits Scheme (PBS) assuming that drugs of similar clinical efficiency and safety shall be reimbursed at the level of lowest-cost product within that therapeutic group. Although PBS system proved well among brand name products, its side effect was the creation of an expensive generic medicines environment in the Australian setting. A serious issue with unaffordability of prescription medicines to the common citizens will likely lead to the administrative change (13).
Taiwan is one of Far Eastern high income economies with prescription and dispensing functions being provided historically by physicians. The lack of separation in these terms make financial incentives targeted to the pharmacists less efficient than in European influenced traditions, because at least half of all dispensing happens in hospitals and clinics. Taiwanese local reports observed patterns of physicians' behavior acting as an imperfect agents actually contributing to "supplier induced demand". As the most essential determinant of generic substitution rates was identified profit margin between the acquisition and reimbursement price. Such scenario allows to medical care providers instead of patients or payers to enjoy additional income arising from reduced brand firm's revenues. Taiwanese experience implies necessity of more efficient policy to improve costeffective prescribing (14)

According to field forecasts, in the following decades emerging pharmaceutical markets of Asia, Eastern Europe and South America will lead in terms of value-based growth worldwide. Ultimately, the two major among BRIC (acronym denounces Brazil, Russia, India and China as major emerging economies) markets, China and India, deserve special attention. India has a growing, globally competitive generic sector which exports its products to over 200 countries. It has a broad spectrum of successfully marketed medicines even in highly regulated settings of high income Western societies. Nevertheless, the quality of some Indian generic products has been questioned by World Health Organization while labeled in its "counterfeit" drugs policy. An in-depth analysis published in response to the damages to Indian generic businesses worldwide proved that generalizations of "lower quality" etiquette should be carefully avoided with regards to numerous highly competitive Indian firms (15). Following the global successes of Indian generic companies under domestic Patents Act from 1970, the first severe threat, came with the international adoption of (TRIPS) Agreement on Trade-Related Aspects of Intellectual Property Rights by World Trade Organization in 1995. It was believed that TRIPS obligations will take the first mover advantage and decrease further Indian expansion into foreign markets. Nevertheless during the course of years Indian legislature adapted towards shortexclusivity strict patentability framework and profit gains remained substantial worldwide.

China on the opposite, exhibits a huge, but highly fragmented pharmaceutical market characterized by unsatisfactory international competitiveness, weak pharmaceutical research investment and poor compliance to the "evidence-based medicine" principles among clinical physicians. Since Deng Xiaoping huge wave of successful economic reforms in late 1970s, Chinese firms have invented only about forty novel chemical compounds 
with a promise of medical indications, unfortunately most still unpatented. Irrational utilization of medicines in China remains a major concern according to WHO. A large share of the market is actually shaped by physicians' behavior in terms of prescribing heavily influenced by their profit margins. Hospitals have significant amount of income based in medicines turnover because drug sales in this middle-income economy in 2006 account for even $41.5 \%$ of an average hospital's total income. These financing patterns create substantially different setting compared to the high income economies where drug acquisition costs account for approximately $15 \%$ of hospital budget and are rather marginal in terms of profit. Poor quality of Chinese prescribing structure indicates that policy efforts aimed at improving generic substitution will have to be persistent to bring fruits in future (16).

We are witnessing the landscape of dynamic BRIC economies involvement in ongoing pharmaceutical market developments worldwide. Therefore it is highly likely that both the generic medicines manufacturers and national regulatory bodies will face growing challenges in the upcoming decades. The promising side of the competition in profit arena is that affordability and accessibility of cheap medicines with decent quality will probably increase in future for the world's poor populations. Hopefully generic market strengthening will also bring more sustainable health care financing to the numerous national health systems currently suffering from severe constrain in available resources for the essential population needs.

\section{ACKNOWLEDGEMENT}

This work was supported by the Ministry of Education, Science and Technological Development, Republic of Serbia Research Grant Nº OI 175014.

\section{REFERENCES}

1. Shepard A. Generic medicines: essential contributors to the long-term health of society. Sector sustainability challenges in Europe. Danbury: IMS Health, 2010. (http://www.imshealth.com/imshealth/Global/ Content/IMS\%20Institute/Documents/Generics Medicines.pdf)

2. Danzon PM, Furukawa MF. Prices and availability of biopharmaceuticals: an international comparison. Health Aff (Millwood) 2006; 25: 1353-62.

3. Decollogny A, Eggli Y, Halfon P, Lufkin TM. Determinants of generic drug substitution in Switzerland. BMC Health Serv Res 2011; 11: 17.
4. Yamada T, Chen CC, Yamada T, Chiu IM, Worrall J. pharmaceutical price control policy, pharmaceutical innovation, and health durability. TOPHARMEJ 2010; 2: 34-46.

5. Sachiko M. The market exclusivity period for new drugs in Japan: overview of intellectual property protection and related regulations. Journal of Generic Medicines 2008; 5: 121-130.

6. Berndt ER, Mortimer R, Bhattacharjya A, Parece A, Tuttle E. Authorized generic drugs, price competition, and consumers' welfare. Health Aff (Millwood) 2007; 26: 790-9.

7. Frank RG. The ongoing regulation of generic drugs. $N$ Engl J Med 2007; 357: 1993-6.

8. Peters JR, Hixon DR, Conner DP, Davit BM, Catterson DM, Parise CM. Generic drugs-safe, effective, and affordable. Dermatol Ther 2009; 22: 229-40.

9. Kuehn BM. Mr Waxman went to Washington: congressman an architect of health laws for 4 decades. JAMA 2014; 311: 1386-8.

10. Jakovljevic MB, Nakazono S, Ogura S. Contemporary generic market in Japan - key conditions to successful evolution. Expert Rev Pharmacoecon Outcomes Res 2014; 14: 181-94.

11. Babar ZU, Grover P, Stewart J, et al. Evaluating pharmacists' views, knowledge, and perception regarding generic medicines in New Zealand. Res Social Adm Pharm 2011; 7: 294-305.

12. Lofgren H. Generic drugs: international trends and policy developments in Australia. Aust Health Rev 2004; 27: 39-48.

13. Searles A, Jefferys S, Doran E, Henry DA. Reference pricing, generic drugs and proposed changes to the Pharmaceutical Benefits Scheme. Med J Aust 2007; 187: 236-9.

14. Liu YM, Yang YH, Hsieh CR. Financial incentives and physicians' prescription decisions on the choice between brand-name and generic drugs: evidence from Taiwan. J Health Econ 2009; 28: 341-9.

15. Shukla N, Sangal T. Generic drug industry in India: the counterfeit spin. Journal of Intellectual Property Rights 2009; 14: 236-240.

16. Sun Q, Santoro MA, Meng Q, Liu C, Eggleston K. Pharmaceutical policy in China. Health Aff (Millwood) 2008; 27: 1042-50. 